\title{
DePois DO PÓS-FORDISMO: AS ÚlTiMAS DÉCADAS DA RAZÃO MATERIAL DO TRABALHO
}

\author{
Breilla $Z A N O N^{*}$
}

RESUMO: Inúmeras são as formas pelas quais o mercado de trabalho buscou lidar com as transformações econômicas nos últimos 50 anos. Dentre essas transformações, a flexibilização marca as novas dinâmicas de produção e de organização dos trabalhadores. O presente artigo tem como objetivo refletir sobre as transformações decorrentes da reestruturação produtiva, observando como a partir desse cenário de estagnação da produtividade fordista - percebida como resultante da rigidez e das burocracias presentes na organização da produção, distribuição e nos mercados -, demandas não só dos consumidores, mas também dos trabalhadores, não podiam mais ser atendidas. O artigo tem como foco o surgimento de um novo perfil de trabalhador, demandado a partir das novas dinâmicas de flexibilização do mercado e de uma nova racionalidade a respeito do trabalho que, no início do século XXI, vai se refletir em novos modelos de organização e gestão do trabalho, como as startups e os coworkings.

PALAVRAS-CHAVE: Pós-fordismo. Reestruturação produtiva. Vale do Silício. Startups. Coworkings.

\section{Introdução}

Nos últimos 50 anos, a flexibilização marcou as novas dinâmicas de produção e de organização dos trabalhadores. A estagnação da produtividade fordista percebida como resultante da rigidez e das burocracias presentes na organização

UFSCar - Universidade Federal de São Carlos. Programa de Pós-Graduação em Sociologia. Laboratório de Estudos sobre Trabalho, Profissões e Mobilidades (LEST-M-UFSCar). São Carlos SP - Brasil. 13565-905 - bzaanon@gmail.com. http://orcid.org/0000-0002-3266-8289. 
da produção, distribuição e nos mercados -, não mais atendia às demandas não só dos consumidores, mas também dos trabalhadores. Era preciso uma nova forma de produzir que possibilitasse uma maior flexibilidade às transações econômicas. O toyotismo ${ }^{1}$, ao introduzir a dinâmica do just-in-time, - baseada na produção por demanda do mercado - eliminava a produção em grande escala, gerando maior eficiência e menores custos para as empresas (ALVES, 2011). Seguindo essa nova configuração, o mercado de trabalho passa a criar dinâmicas e perfis de trabalhadores mais flexíveis, dispostos a atender a essa nova demanda (SENNETT, 2009).

O período da reestruturação produtiva pode ser entendido também como o catalisador - e resultado ao mesmo tempo - daquilo que autores como Castells (2003) chamam de Revolução Informacional. Trata-se de um momento em que, consequentemente, os mercados passam a demandar por uma maior qualificação dos trabalhadores, favorecendo o aumento da categoria dos profissionais especializados. Vemos, portanto, dois processos que se entrelaçam e contribuem de maneira articulada a toda uma reconfiguração do cenário produtivo e do trabalho. Se olharmos o desenvolvimento tecnológico em retrospectiva, podemos observar que esse gerou um avanço material e social amplo e intenso nas dimensões mais diversas. Não é difícil entender, então, o motivo pelo qual sociólogos como o próprio Castells (2003) consideram as transformações que tais tecnologias renderam às sociedades, algo de impacto semelhante ao que foi conduzido pelas Revoluções Industriais. Foi no final do século XX, mais especificamente a partir da década de 1970, que as transformações tecnológicas passaram a ser extensamente sentidas em meio a sociedade civil. Assim, as novas tecnologias abriram um novo curso socioeconômico: trouxeram soluções eficazes aos entraves que já vinham sendo apresentados pelo fordismo uma década antes, e contribuiu para a oxigenação dos mercados em um período que ainda se sentia os impactos, sobretudo econômicos e políticos, do pós-guerra (ATHIQUE, 2013).

[...] A nova centralidade da gestão da informação, no entanto, posteriormente provou ser um desenvolvimento igualmente profundo no refazer do mundo moderno. Na década de 1970, entramos em uma era em que vastos armazenamentos de informações pareceram ter maior significado do que grandes volumes de recursos físicos. Todas as formas de processos, conceitos e atividades humanas estavam sendo registradas e, por sua vez, foram aplicadas e melhoradas pela maquinaria da tecnologia da informação. [...] Os benefícios da maior velocidade e eficiência no processamento da informação também foram evidentes para os vários ramos

\footnotetext{
1 Taiichi Ohno é considerado o criador desse sistema, o qual tem como base o modo de produção flexível just-in-time, que elimina a produção em grande em escala, gerando maior eficiência e menores custos para as empresas (ALVES, 2011).
} 


\section{Depois do pós-fordismo: as últimas décadas da razão material do trabalho}

do governo moderno e as corporações comerciais da atualidade (ATHIQUE, 2013, p.7-8, tradução nossa).

Em paralelo às turbulências que movimentavam o campo da economia nesse período, as reivindicações dos trabalhadores ampliavam as discussões acerca de melhores condições de trabalho e mais autonomia em relação às dinâmicas rígidas que a organização fordista impunha até então. Maio de 1968 talvez tenha sido o episódio mais emblemático de todas essas manifestações que demandavam por mais acessos e direitos à sociedade civil, transbordando a esfera da economia para questões de interesse político e social (HARDT; NEGRI, 2001).

Toda essa nova configuração dá início a um período que convencionamos chamar de pós-fordista, um momento em que as técnicas de trabalho humano e material passam das estratégias tayloristas de repetição e planificação, para produções flexíveis, sob demanda do mercado, aliando agilidade do processo produtivo sob demanda à diminuição de custos (HARVEY, 2012). Inserem-se com isso novos valores em meio ao mercado de trabalho, o que significa que um novo perfil de trabalhador, com um outro tipo de racionalidade em relação a sua condição, passa a ser constituído (SENNETT, 2009). A flexibilidade passa a ser prerrogativa para as transações de mercado como um todo. O período pós-fordista deixa evidente a maneira pela qual a transformação da produção material vai se espraiando pelas relações de reprodução social dos indivíduos nas mais diversas dimensões da vida.

De acordo com Sennett (2009) e Harvey (2012), a flexibilidade que se requer nesse momento não se refere somente à dimensão da produção, mas está totalmente relacionada também à própria estrutura do mercado de trabalho e às transformações pelas quais os trabalhadores são obrigados a passar no que diz respeito às suas condutas para se adaptarem a essa nova configuração. $\mathrm{O}$ intenso fluxo informacional, junto com suas respectivas tecnologias, permite que tempo e espaço sejam resignificados, e junto com eles, a própria posição dos indivíduos dentro do mercado de trabalho.

O mercado de trabalho [...] passou por uma radical reestruturação. Diante da forte volatilidade do mercado, do aumento da competição e do estreitamento das margens de lucro, os patrões tiraram proveito do enfraquecimento do poder sindical e da grande quantidade de mão-de-obra excedente (desempregados ou subempregados) para impor regimes e contratos de trabalho mais flexíveis. (HARVEY, 2012, p.143).

Sejam como catalizadores ou como resultantes, em síntese, os debates sobre as transformações ocorridas a partir da reestruturação produtiva concordam que a entrada de novas tecnologias na cadeia de produção, e a decorrente transformação 
da organização do trabalho e de suas relações em condições mais flexibilizadas, alimentaram a instabilidade e fragmentariedade dos mercados de trabalho, levando a um enfraquecimento dos sindicatos trabalhistas (HARVEY, 2012).

O que vemos é o resultado da articulação dessas transformações econômicas, políticas, tecnológicas e sociais. Não se trata de dizer qual o princípio que desencadeou cada uma delas, nem de colocá-las em um grau de hierarquia, mas de pensarmos como todos esses acontecimentos, de maneira articulada, permitiram que uma nova racionalidade fosse concebida e com ela uma nova interpretação do trabalhador a respeito de si mesmo e do seu trabalho. Uma nova subjetividade começa a se moldar e o que vemos hoje a partir de espaços de trabalho flexíveis como as startups ${ }^{2}$ e os coworkings ${ }^{3}$ são não mais que reflexos de todo esse processo.

\section{Um novo perfil de trabalhador ou a reengenharia do mercado de trabalho em dois momentos}

A tecnologia da informação dentro dos processos de produção garantiu que a reestruturação produtiva gerasse um avanço não só no que tange a alta produtividade a baixos custos, mas também permitiu uma reorganização das relações de trabalho. Os espaços de coworking e as startups surgem na esteira dos processos de reengenharia dos mercados de trabalho que acontecem nesse período. Entendemos que esse cenário se desenha em dois momentos: o primeiro deles corresponde à inserção da tecnologia nos processos de produção logo nos primeiros anos da década de 1970, o que acaba por eliminar uma mão de obra mais mecânica e menos qualificada, substituindo-a por novas tecnologias e profissionais qualificados no seu manuseio (SENNETT, 2009). Ao final da década de 1990, observamos um segundo movimento semelhante, cujo intuito era mais uma vez reorganizar o perfil de trabalhadores dentro da escala produtiva. Trata-se de um período histórico onde a internet passa a ser o principal centro das atenções mercantis da época. Seu potencial econômico começa a ser explorado com mais intensidade a medida em que as empresas voltadas para o desenvolvimento de negócios via internet - conhecidas como ponto.com - deixam de ser algo fora da realidade de mercado.

Mais uma onda de desemprego vai se desencadear, no entanto, ela se refere ao estouro da bolha que o intenso fluxo de investimentos e especulação começa

\footnotetext{
2 Startups podem ser definidas como empresas de pequeno porte em fase inicial de investimento que se proliferaram a partir da década de 1990 (GITAHI, 2010), mas também podem ser consideradas um modelo de gestão pautado na inovação, método e escalabilidade.

3 Coworkings são espaços de trabalho compartilhados por profissionais diversos, em sua maioria autônomos, aonde são divididos os custos de aluguel, de materiais de trabalho em comum, e de manutenção do espaço, por meio dos quais se é possível aumentar as oportunidades de networking e diminuir o isolamento do home-office.
} 
a formar entorno dessa nova forma de empreender. Com uma alta aplicação de capital em uma dimensão do mercado que ainda estava se consolidando, muitas empresas acabam não atingindo o resultado esperado diante de grande instabilidade $\mathrm{e}$ concorrência, e mais uma onda de trabalhadores - sobretudo jovens e qualificados se vê em condição de desemprego (MANN; NUNES, 2009). O que vemos, portanto, a partir desses dois momentos, são dois tipos consecutivos de trabalhadores à deriva nesse período de transformações: no primeiro deles, um trabalhador mais experiente, porém menos qualificado no que diz respeito às novas demandas tecnológicas, tendo apenas um conhecimento mais técnico da produção e, por isso, exposto a um intenso processo de adaptação, (SENNETT, 2009) e, posteriormente, uma categoria de trabalhadores mais jovens, que já havia entrado no mercado de trabalho em certa medida em substituição a um perfil mais rígido e técnico de profissional, e que acumulava em seu currículo conhecimentos mais qualificados, ligados a uma grande influência da demanda por tecnologia, ao fluxo de informação e à cientificidade no mercado de trabalho.

É importante diferenciar esses dois tipos de trabalhadores, pois eles indicam a racionalidade por trás das transformações econômicas. Entender o processo de reengenharia do trabalho em duas fases nos ajuda a visualizar uma complementariedade e um curso lógico da forma pela qual o mercado passa a organizar a gestão de seus trabalhadores. Em síntese, vemos no primeiro momento uma onda de desemprego de trabalhadores em decorrência da substituição por ferramentas de automação da produção que tinha como objetivo pôr em prática a estratégia toyotista do lean production, ou seja, da produção enxuta (SENNETT, 2009). Anos mais tarde, a qualificação técnica a respeito das novas ferramentas tecnológicas parecia não mais ser suficiente para contemplar as demandas do mercado. Um novo perfil de trabalhador era necessário e isso significava trabalhadores cuja subjetividade estivesse envolvida com o mercado para além dos atributos técnicos. Esse novo trabalhador deveria ser ainda mais flexível, dotado de uma subjetividade cujos afetos e desejos fossem capazes de se adaptar às intempéries, fragilidades e interesses do mercado e, assim, deveria estar consequentemente disposto a dedicar sua vida e talentos à empresa (LAVAL; DARDOT, 2016).

Mais do que aqueles trabalhadores que foram lançados à sorte no início da reestruturação produtiva, os trabalhadores que se deparam com o desemprego no contexto dado pela bolha da internet se veem diante de uma demanda toyotista intensificada, onde as práticas de gestão do trabalho passaram a dar mais privilégio por um profissional que se disponibilizasse a um constante processo de inovação de seus conhecimentos como forma de garantir sua empregabilidade. Além disso, novos cargos e ocupações são criados ou renomeados dentro das empresas ${ }^{4}$, mas não

4 Essa estratégia das empresas é definida por Standing (2013, p.38) como uptitling. 
de maneira a criar novos custos, e sim como forma de dar um outro significado a atividades que até então não eram valorizadas, dando ao trabalhador a falsa sensação de ascensão na carreira (STANDING, 2013). Todo o processo de reengenharia do mercado de trabalho que se estabelece a partir da reestruturação produtiva e se intensifica com o período de recessão que se estabelece após o estouro da bolha da internet vai ao encontro, portanto, do projeto de enxugamento das empresas e da progressiva incorporação da subjetividade e vida dos trabalhadores aos interesses do capital.

Do ponto de vista da origem das primeiras startups e espaços de coworking, vemos uma consonância do aparecimento de suas primeiras experiências com esses dois processos de reengenharia. Primeiro porque é partir da reestruturação produtiva, desencadeada na década de 1970, que um perfil de trabalhador mais qualificado passa a ser exigido pelo mercado de trabalho e, segundo, porque a progressiva transformação da subjetividade dos trabalhadores - que consecutivamente é resultado da transformação do perfil de trabalhador demandado pelo mercado passa a configurar novos desejos e interesses dos mesmos a respeito daquilo que para eles seria o trabalho ideal. Dessa maneira, observamos que o perfil de trabalhador que a princípio se apresenta nas startups e espaços de coworking tem uma forte relação com o desemprego que assolou os grandes centros europeus e americanos nas últimas décadas. Trata-se de sujeitos que presenciaram um processo de transformação do mercado de trabalho e, consequentemente, do perfil de trabalhador, que se inicia na década de 1970, mas que se intensifica nas primeiras décadas dos anos 2000. Suas subjetividades vão sendo cada vez mais mobilizadas em função das novas formas de gestão. Forja-se assim, no decorrer de todo esse período, um trabalhador cujos desejos e interesses que o identificam, se encontram alinhados às motivações do mercado capitalista. Trata-se de sujeitos com alto nível de formação e especialização, mas, sobretudo, trabalhadores cuja subjetividade se mobiliza no sentido de incorporar sem muita resistência o comportamento flexível, uma vez que esse passa a ser demandado pelas empresas e entendido por eles como requisito de empregabilidade (ZANON, 2015).

Assim, diante de todas essas condições, o perfil de trabalhadores tanto das startups quanto dos coworkings são muito semelhantes: a média de idade dentro dos espaços de coworking e dentro das startups gira em torno dos 25 a 40 anos, sendo que nos espaços de coworking a faixa etária dos empreendedores é de 35 anos e nas startups, essa faixa média é de 28 anos (PELISSON; HARTMANS, 2017). Os dois modelos são predominados por homens ( $53 \%$ e $81 \%$ dos coworkers e dos empreendedores de startups, respectivamente, são do gênero masculino). Já no que diz respeito ao nível de escolaridade, $86 \%$ dos coworkers são graduados ou pós-graduados, assim como $95 \%$ dos empreendedores de startups. Podemos ver, 
portanto, um perfil de profissionais que se aproxima nesses dois modelos: homens jovens e com nível superior de ensino (DESKMAG, 2017; FIRST ROUND, 2017).

Um ponto interessante na trajetória desses profissionais é que, no processo de origem desses espaços, muitos deles inicialmente trabalhavam em empresas e depois, mediante o processo de reengenharia, são demitidos ou passam a trabalhar em casa ou remotamente como uma forma de cortar gastos por parte das empresas ${ }^{5}$. Outros, quando mais jovens, já são formados a pensar o mercado de trabalho por meio de uma perspectiva mais flexível e instável, ou que a seguridade, no caso, seria fruto de seu próprio desempenho.

No entanto, toda essa nova atmosfera de pró-atividade disseminada em meio ao mundo do trabalho nas últimas décadas, esconde condições que podem ser entendidas como movimentos de precarização que se disfarçam em discursos de autonomia e liberdade. Trata-se de uma nova mentalidade apresentada em um processo de formação de trabalhadores que vai além das cadeiras da universidade e que se constroem em consonância a toda uma racionalidade neoliberal que reforça os processos de individualização e responsabilização do trabalhador, usando para isso o nome de "autonomia empreendedora" (LAVAL; DARDOT, 2016). Isso acontece porque ao mesmo tempo em que esses modelos criam oportunidades de conexão, exigem mais do trabalhador e transferem para ele toda a responsabilidade de seu sucesso e competência. Assim, podemos observar também uma mudança gradativa das estratégias de exploração. É na lógica da reestruturação produtiva que a racionalidade neoliberal se define: ampliam-se as formas pelas quais essas estratégias se valem da responsabilização, fazendo uso de discursos motivacionais e atributos que afetam cada vez mais a subjetividade do trabalhador na tentativa de refinar as técnicas de diluição das fronteiras entre o trabalho e a vida do trabalhador.

O toyotismo, em oposição ao taylorismo, não vê diferença entre concepção, controle e execução. Com isso, os trabalhadores tornam-se mais responsáveis pelo processo produtivo como um todo, menos alienados.

Ao lado disso, a proposta é de uma certa liberação generalizada, à medida que uma mobilidade é estimulada, é valorizado aquele que pode trabalhar com pessoas muito diferentes, que está aberto e flexível a trabalhar em projetos distintos, adaptar-se a circunstâncias diversas, e cada projeto é uma oportunidade para enriquecer as competências próprias e aumentar a empregabilidade. Com isso, de fato o neomanagement responde às críticas anteriores no tocante do controle hierárquico, outorgando uma margem de liberdade, reivindicando mesmo uma

\footnotetext{
5 A relação de proliferação das startups, surgimento dos espaços de coworking e desemprego não diz respeito ao surgimento das primeiras experiências desses modelos surgidas na América do Norte e na Europa, respectivamente.
} 
autonomia, uma espontaneidade, uma mobilidade, uma pluricompetência, uma convivialidade, uma abertura à novidade, à criatividade, à sensibilidade, a escuta do vivido e o acolhimento de experiências múltiplas, contatos interpessoais etc. [...] Mas se esses temas eram associados a uma crítica radical ao capitalismo, agora, são valorizados por si mesmos e postos a trabalhar em favor daquilo que ontem eles criticavam. (PELBART, 2003, p.99).

Standing (2013) nos oferece alguns elementos para pensarmos sobre esse novo perfil de trabalhador a partir dos processos de precarização do trabalho. Esse autor define como precariado uma categoria de profissionais que emerge de um movimento de jovens europeus instruídos e descontentes com a competição imposta pelo mercado. Trata-se de trabalhadores que vivenciam as primeiras fases das transformações que o intenso fluxo de informação veio proporcionar. Apesar de não ser uma categoria homogênea, existe uma condição em comum: trata-se de pessoas que, sob a organização neoliberal do mundo do trabalho, se encontram sem âncora, sem estabilidade e por isso, compartilham de uma existência precarizada, ou seja, definida por baixos salários, pouca ou nenhuma proteção no emprego, trabalhos temporários ou sob demanda, e apelo às competências do trabalhador como forma de autoresponsabilizá-lo sobre seu desempenho. Por ser também uma categoria que não têm uma identidade fixa, mas que compartilha suas referências com pessoas cujo estilo de vida não corresponde aos interesses convencionais do capital, o precariado não se identifica com as pautas sindicais e trabalhistas que até décadas anteriores promoviam uma sensação de segurança entre os trabalhadores fordistas. O argumento de Standing (2013) é que a flexibilização da economia e seus reflexos no mercado de trabalho estabeleceram um ambiente de insegurança entre os trabalhadores e esse seria o componente principal da identidade dessa que, para ele, ainda seria uma classe em formação devido a sua fragmentariedade.

No entanto, o que nos interessa dessa análise é o debate que observa nessa categoria, também, a internalização por parte desses trabalhadores de que a existência precária nada mais seria que um estado de vida normal dentro de nossa realidade e que, apesar de não terem a partir disso esperança na integração social, acabam por tomarem para si uma identidade de trabalhador de "espírito livre", percepção a qual é constantemente alimentada pelos discursos motivacionais voltados para o trabalho pós-fordista. Assim, a falta de uma identidade fixa que defina o precariado, nem sempre é entendida como algo ruim por aqueles que dele fazem parte, pelo contrário: muitas vezes passa a ser interpretada como liberdade pelo fato de não se ter nenhum comprometimento moral estabelecido pelo trabalho. Assim, a instabilidade de um trabalhador que trabalha por projeto ou sob qualquer outra forma de contrato temporário passa a ser exaltada como oportunidades de mobilidade dentro do mercado de trabalho, ou seja, o verdadeiro "nômade urbano". 


\section{Depois do pós-fordismo: as últimas décadas da razão material do trabalho}

Trazer as reflexões a respeito do precariado torna-se importante para nossa análise na medida em que ela demonstra como a falta de seguridade dentro do trabalho provocada pelo fortalecimento da agenda neoliberal, influencia na subjetividade do trabalhador, dando base a um perfil de profissional que apesar de enfatizar a dimensão da comunidade e do compartilhamento, não mais reconhece as relações de confiança forjadas dentro da atividade laboral, pois para ele, manter-se flexível é significado de liberdade.

Dito isso, nosso principal argumento é que existe uma relação direta entre o surgimento das startups e o aparecimento dos espaços de coworking e essa relação se fundamenta em uma nova racionalidade econômica, projetada por um contexto político transformado que entra em cena a partir da reestruturação produtiva e da revolução informacional. Acreditamos que as startups e os espaços de coworking aparecem como modelos complementares de forma e organização do trabalho dentro desse recorte específico de tempo e contexto, envolvendo nessa atmosfera profissionais que não mais se encaixam no perfil de trabalhador fordista. Trata-se, portanto, de um trabalhador que tem intensificado em si as demandas de individualização, flexibilidade e responsabilização inauguradas pelo toyotismo. Por isso, para seguirmos adiante, precisamos observar como as transformações econômicas desencadeadas a partir da crise de produção fordista dos anos de 1970 propiciou um contexto favorável e flexível para que essas experiências e conjunções viessem a ser possíveis anos mais tarde, na década de 1990.

\section{Um espírito ronda o Vale: novas formas de organização empresarial e do trabalho}

Durante o exercício de fazer um resgate histórico e sociológico dos elementos contextuais que permitiram o aparecimento das startups e dos espaços de coworking, observamos o quanto seria importante nos debruçar sobre o papel do Vale do Silício. Se Manchester rendeu repertório a uma das principais análises econômicas e políticas do século XIX por ter sido o grande epicentro de transformações técnicas e organizacionais que iriam transbordar para o mundo do trabalho de maneira global, o Vale do Silício nos oferece hoje condições muito semelhantes para desenvolvermos as observações de que nosso tempo necessita. A importância de se dar foco para essa região de São Francisco, nos Estados Unidos da América (EUA), deve-se ao momento que ficou conhecido como bolha da internet (RIES, 2012). Ele pode ser entendido como período em que foram criadas as condições e um ambiente favorável a ideias vinculadas à economia compartilhada e inovação como modelo de gestão, as quais iriam corresponder tanto à proliferação das startups como ao surgimento dos espaços de coworking originalmente a partir do Vale do Silício. 
O Vale, como amigavelmente chamam os empreendedores que lá habitam (MARTEL, 2015), está geograficamente localizado no sul da baía da cidade de São Francisco (USA), na região norte da Califórnia, pegando uma área que vai desde a cidade de São José até a cidade de São Francisco.

Figura 1 - Mapa do Vale do Silício

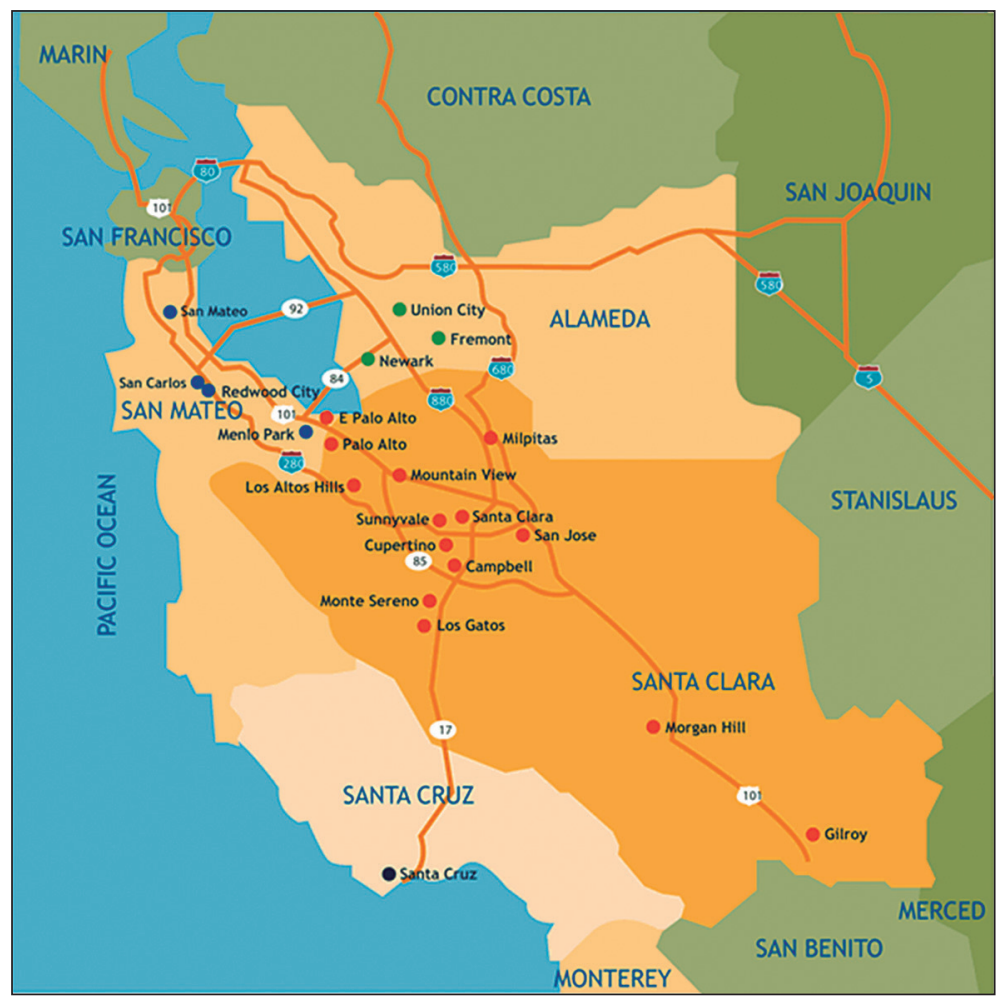

Fonte: https://pearson-realty.com/SiliconValley

A história do Vale do Silício remonta ao século XIX e já mostra que sua construção se deu em meio a uma cultura diferenciada no que diz respeito à diversidade e à ética do trabalho que envolvem o local. Isso porque é nessa região que em 1849 acontece aquilo que foi chamado a "Corrida do Ouro", ocasião que transforma uma área que contava até então com 200 habitantes em uma aglomeração com 30 mil pessoas em um curto período de três anos. A Corrida do Ouro atrai para a baía de São Francisco milhares de aventureiros que buscavam encontrar naquele local as oportunidades de mudar de vida. É nessa época que começa a se delinear toda cultura que fundamentaria aquilo que muitos dizem ser a mística existente no Vale do Silício. Assim, de acordo com Normand (2014), o risco e a ambição, tão 
inerentes ao espírito empreendedor, é algo, portanto, que, junto à diversidade que a região passa a aglomerar, vai contaminar diretamente a cultura local que começa a se definir naquele território a partir de então.

Figura 2 - Anúncio de embarques para Califórnia na época da Corrida do Ouro

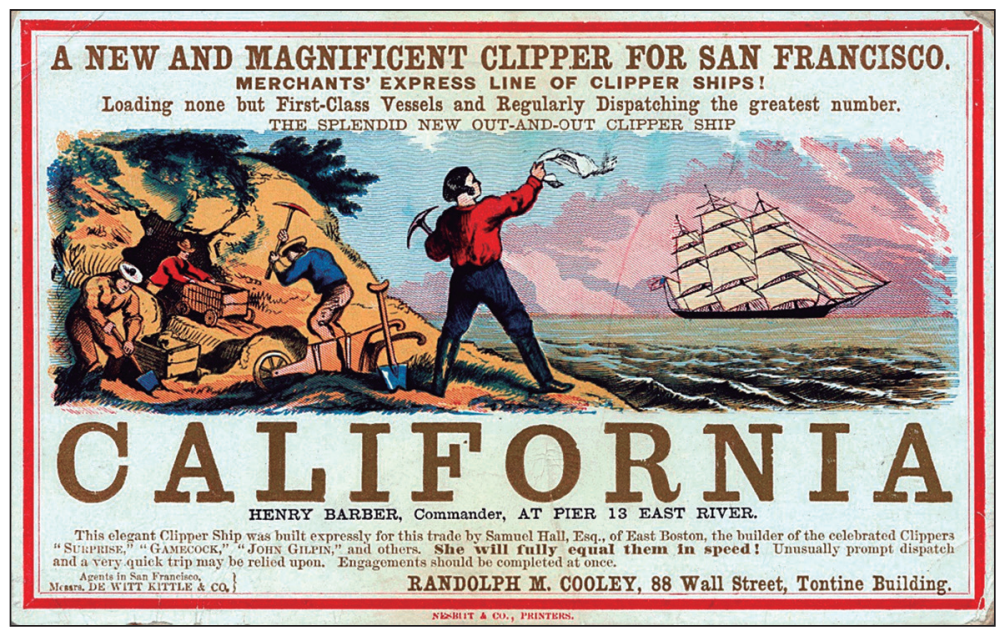

Fonte: https://www.geologyforinvestors.com/california-gold-rush/

Figura 3 - Santa Clara Valley, região que mais tarde se tornaria o Vale do Silício (1920)

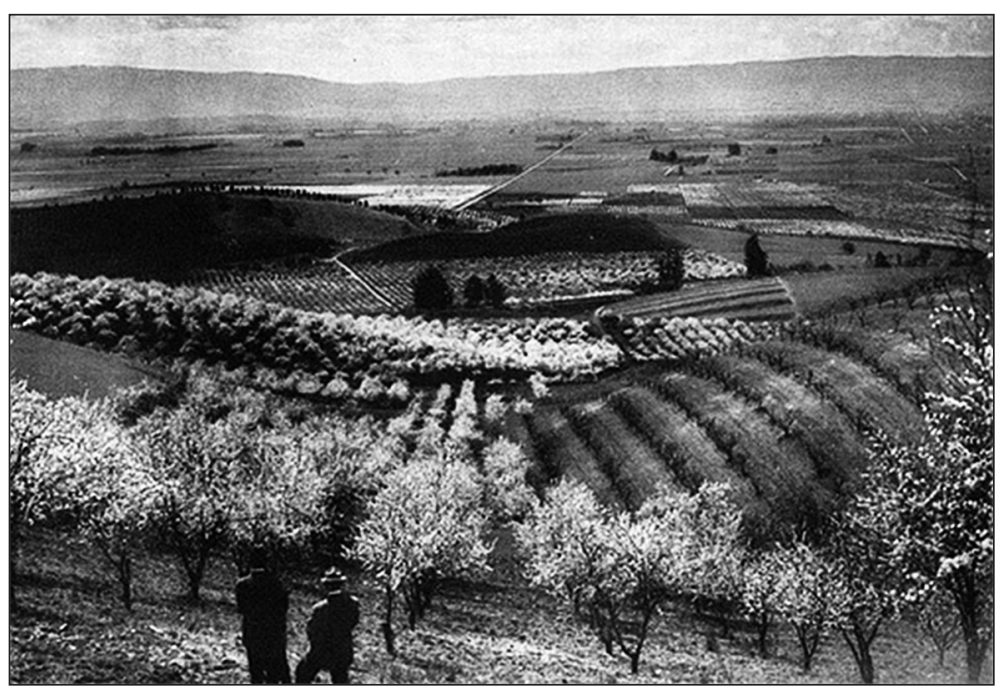

Fonte: http://www.businessinsider.com/vintage-silicon-valley-photos-2014-7 
Já nas primeiras décadas do século XX, estudos na área de tecnologia adentram o Vale do Silício. Nos anos entre 1909 e 1912, na região de Palo Alto, dáse início às pesquisas sobre sistemas de comunicação via rádio. É dali em diante que a tecnologia começa a ser algo que passa a dar a cara do Vale do Silício. Durante as décadas de 1930 e 1950, pesquisas aeroespaciais e militares são desenvolvidas por lá, muitas delas com o apoio financeiro do governo dos Estados Unidos. A partir desse período, Frederick Terman, então reitor da Universidade de Stanford, passa a incentivar alunos e professores a abrirem suas próprias empresas voltadas para a tecnologia no entorno da Universidade. É nesse período - década de 1950 - que, com a invenção do transistor e do uso do silício como material semicondutor base para a produção do microchip e dos microprocessadores elementares para a fabricação de computadores - que começa a se constituir o que anos mais tarde desencadearia na chamada "Segunda Corrida do Ouro" da região. É também nessa mesma época que surge a arpanet, protótipo militar da internet que conhecemos hoje (DULLIUS, 2016; MILSKOLCI, 2014).

É ainda em 1950 que William Shockley, um dos pesquisadores envolvidos na criação dos semicondutores, usa de sua fama como ganhador de um Prêmio Nobel em Física para recrutar jovens talentos da área, vindos de Boston e Nova York regiões consideradas o centro das grandes criações tecnológicas até então -, para abrir aquilo que seria considerada a primeira startup do Vale do Silício, a Shockley Semiconductors. Assim como ocorre comumente em muitas startups, como veremos adiante, a Shockley também foi o primeiro fracasso do Vale. No entanto, dois de seus pesquisadores não se deixaram abalar pela situação de desemprego e fundaram a Fairchild Semiconductor (MORRIS; PENIDO, 2014).

Atento a essas inovações e ao protagonismo de Shockley, o jornalista Don Hoefler batiza a região com o nome de Vale do Silício, em um artigo de 1971 para o jornal Eletronic News. Hoefler fazia alusão ao vale agrícola que se instalava nessa localização no início da década de 1920 (Figura 2) e à descoberta e uso do silício na produção de microchips, o que viria a se tornar o motor central da economia daquele lugar. Na época, a região era até então conhecida como Santa Clara Valley (LAWS, 2015). 
Figura 4 - Trecho do artigo de Don Hoefler publicado na Eletronic News (1971)

\begin{tabular}{|c|}
\hline $\begin{array}{l}\text { (This is the first of a three-part series on the history of the semiconduc- } \\
\text { tor industry in the Bay Area. a behindd-the-scenes report of the men. money. } \\
\text { and litigation which spawned } 23 \text { companies - from the fledgling rebels of } \\
\text { Shockley Transistor to the present day.) } \\
\text { By DON C. HOEFLER } \\
\text { It was not a vintage year for semiconductor start-ups. } \\
\text { Yet the } 1970 \text { year-end box score on the San Francisco Penin- } \\
\text { sula and Santa Clara Valley of California found four more } \\
\text { new entries in the IC sweeps, one more than in } 1969 \text {. } \\
\text { The pace has been so frantic that even hardened veter- } \\
\text { ans of the semiconductor wars find it hard to realize that the } \\
\text { Bay Area story covers an era of only } 15 \text { years. And only } 23 \\
\text { years have passed since the invention of the transistor, } \\
\text { which made it all possible. } \\
\text { For the story really begins on the day before Christmas } \\
\text { Eve, Dec. } 23 \text {, 1947. That was the day, at Bell Telephone } \\
\text { Laboratories in Murray Hill, N.J., three distinguished scien- } \\
\text { tists, Dr. John Bardeen, Dr. Walter Brattain and Dr. William } \\
\text { Shockley, demonstrated the first successful transistor. It was } \\
\text { made of germanium, a point-contact device that looked } \\
\text { something like a crystal detector, complete with cat's whis- } \\
\text { kers. } \\
\text { The three inventors won the Nobel Prize for their ef- } \\
\text { forts, but only one of them, Dr. Shcckley, was determined to } \\
\text { capitalize on the transistor commercially. In him lies the } \\
\text { genesis of the San Francisco silicon story. } \\
\text { It was only by a quirk of fate, however, coupled with } \\
\text { lack of management foresight, that Boston failed to become } \\
\text { the major semiconductor center San Francisco is today. } \\
\text { When Dr. Shockley left Bell Labs in } 1954 \text {, he headed first for } \\
\text { New England to become a consultant to Raytheon Co., with a } \\
\text { view toward establishing a semiconductor firm there under } \\
\text { its auspices. }\end{array}$ \\
\hline
\end{tabular}

Fonte: http://www.computerhistory.org/atchm/who-named-silicon-valley/

Figura 5 - Os oito empreendedores da FairChild Semiconductors

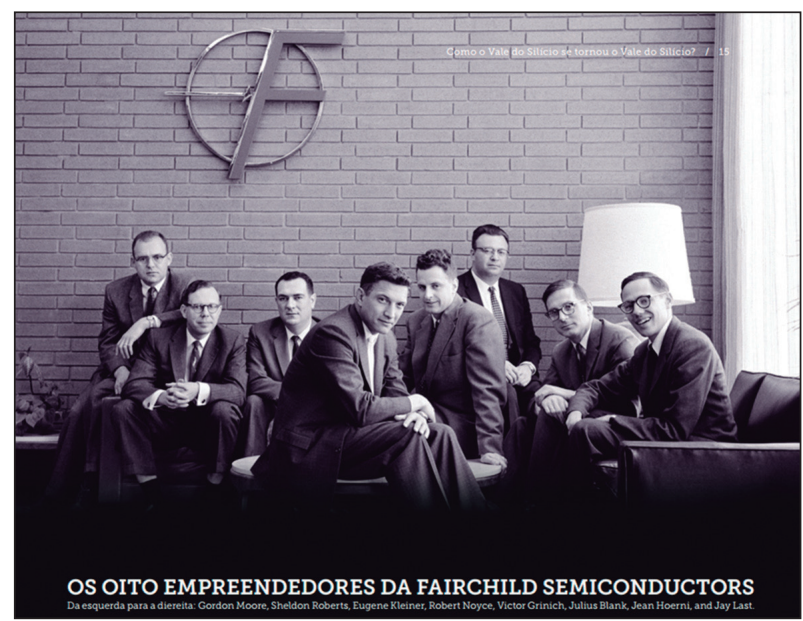

Fonte: https://endeavor.org.br/como-o-vale-silicio-se-tornou-o-vale-silicio/ 
A Fairchild, de certa forma, ajudou a moldar a cara que o Vale do Silício viria a ter no futuro. Ela daria origem a 31 outros empreendimentos, as chamadas spinoffs $^{6}$ - sendo uma delas a Intel - em um período de apenas 12 anos (MORRIS; PENIDO, 2014).

Figura 6 - Spinoffs originadas a partir da FairChild Semiconductors

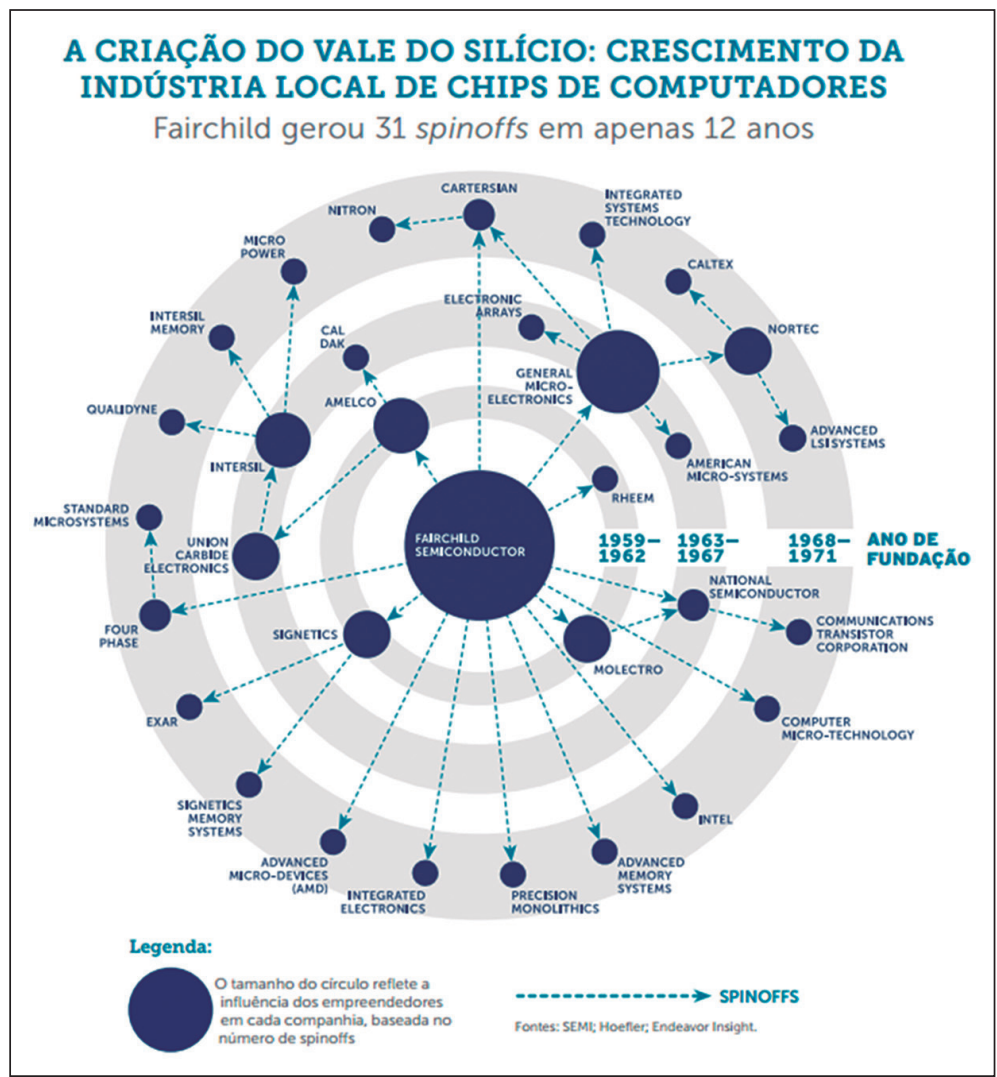

Fonte: https://endeavor.org.br/como-o-vale-silicio-se-tornou-o-vale-silicio/

Não é difícil entender, portanto, como essa proliferação de criações tecnológicas passam a atrair investimentos governamentais milionários e, anos mais tarde, na década de 1970, transforma o Vale do Silício em um verdadeiro polo de investidores de capital de risco que buscavam aplicar seus investimentos em empresas voltadas para inovação. Consequentemente, a região do Vale do Silício passa a dizer muito a respeito do surgimento das startups e coworkings. Diante de todo o histórico

6 Spinoffs são empresas secundárias que derivam de empreendimentos maiores. Disponível em: https:// www.dicionariofinanceiro.com/spin-off/ . Acesso em: 03 ago. 2018. 
cultural e econômico da região, ele se transforma em uma área capaz de concentrar profissionais cuja racionalidade, perfis e desejos depositados em relação ao trabalho eram diametralmente opostos aos trabalhadores das décadas anteriores, marcados pela dinâmica fordista de trabalho (THIEL; MASTERS, 2014).

Figura 7 - Vista aérea do Vale do Silício (2017)

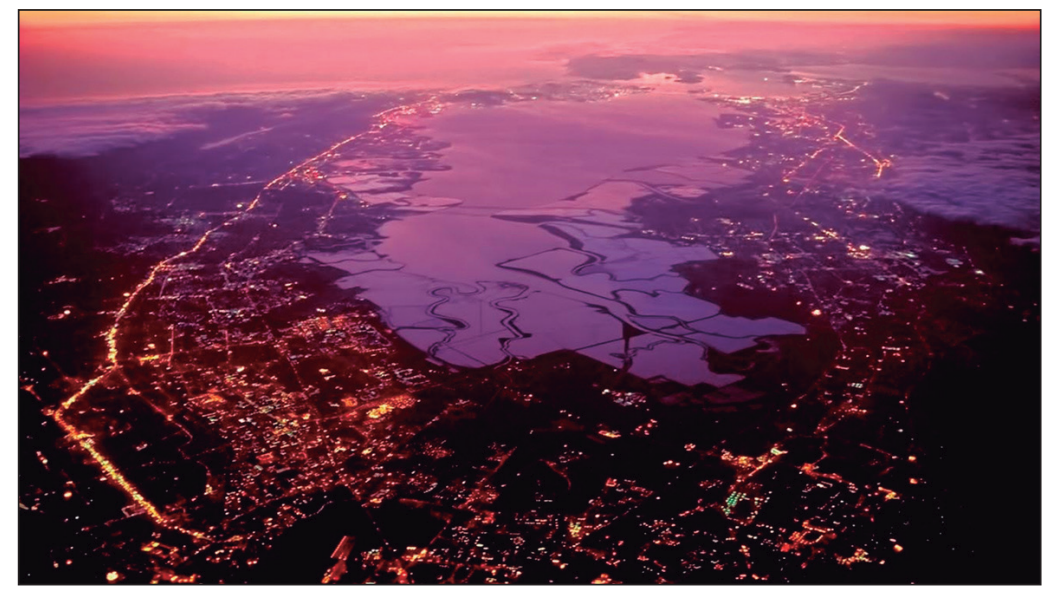

Fonte: http://diversitytechweek.org/locations/silicon-valley/2018-silicon-valleytech-diversity-week/

O Vale do Silício nos ajuda a perceber de que maneira novas demandas e valores passaram a circular em meio ao mundo do trabalho e configurar um novo momento pós-fordista. Apesar de todos os elementos que tornaram possível sua atmosfera começarem a serem organizados desde a segunda metade do século XIX, é a partir da década de 1970 que ele passa a ter as proporções que vemos hoje, deslocando para lá os centros tecnológicos - e consequentemente o investimento em pesquisa - que até então se encontravam em Boston e Nova York (MORRIS; PENIDO, 2014).

O Vale do Silício ilustra aquilo que autores como Laval e Dardot (2016) mais tarde vão elaborar teoricamente como sendo uma nova configuração sob a qual o capitalismo passa a se orientar por meio de uma nova racionalidade - e por isso novas formas de organização, disciplinarização e de subjetividades. Como já salientamos, trata-se de um momento onde existe a necessidade prática de pensar a economia e a produtividade partindo de demandas por mais flexibilidade que já vinham sendo colocadas em pauta tanto por parte do mercado consumidor, quanto por parte dos próprios trabalhadores (BOLTANSKY; CHIAPELLO, 2009; LAVAL; DARDOT, 2016). Por isso, torna-se fundamental recorrermos à história do Vale do Silício para refletirmos sobre a reestruturação produtiva e sua influência no 
surgimento das primeiras startups, uma vez que as primeiras experiências desses modelos surgem nessa região. O Vale do Silício foi capaz de aglutinar todos os elementos contextuais - sobretudo no que diz respeito à cultura e à matéria-prima a uma nova fase da demanda econômica, na qual a informação e a tecnologia teriam centralidade. Trata-se, portanto, de um espaço em que podemos ver os efeitos dessas transformações, em especial no que tange a essa nova racionalidade de um determinado perfil de trabalhador: jovem, qualificado, de classe média, ligado a atividades que envolvem - mais ou menos intensamente - tecnologias informacionais.

Assim, o que torna o Vale do Silício um contexto interessante é um misto de elementos. Elementos esses que entram em concordância - mas também trazem avanços - àquilo que Schumpeter (1997) já havia salientado muitos anos antes em suas observações sobre a figura e o contexto do empreendedor. No Vale foi possível encontrar materiais necessários para a construção de $\operatorname{hardwares}^{7}$ sofisticados, o que, consequentemente, o tornou um local privilegiado e visado para o investimento em criação e o seu desenvolvimento em grande escala. Tais fatos também possibilitaram que o local abrigasse uma das maiores instituições de ensino voltada principalmente para tecnologias digitais, a Universidade de Stanford, considerada por muitos o coração do Vale do Silício (MARTEL, 2015). Não foi, portanto, a toa que o local deu origem a figuras responsáveis por grandes revoluções dentro da área computacional e da informação, como Steve Jobs (Apple), Bill Gates (Microsoft), Mark Zuckerberg (Facebook).

Os ingredientes que fazem o Vale do Silício lhe são próprios: as intersecções entre os mundos da pesquisa, das finanças e do empreendedorismo, sua porosidade e sua permeabilidade; a diversidade cultural e linguística específica da Califórnia; a fé na iniciativa pessoal, o evangelho da empresa e a tolerância com o fracasso; determinada ética protestante do trabalho e do capitalismo; uma relação com a riqueza que oscila entre a filantropia e a cupidez; o sonho de uma utopia digital; o otimismo; a massa crítica e a scalability; um jeito muito particular de ao mesmo tempo viver na comunidade e cultivar sua diferença; o secret sauce de Stanford; a contracultura de São Francisco - todos esses elementos não são facilmente suscetíveis de reprodução em outros lugares. (MARTEL, 2015, p.38-39).

As startups ganharam força em meio a uma multidão de jovens trabalhadores ligados à tecnologia, que viam naquele local um ambiente propício tanto financeiramente quanto simbolicamente para fomentarem suas ideias inovadoras

\footnotetext{
7 Hardware: Os componentes eletrônicos, placas, periféricos e outros equipamentos que formam um computador - em contraste com os programas (softwares) que controlam o funcionamento desses componentes, conforme Márcia Regina Sawaya no Dicionário de Informática e Internet (1999).
} 
(THIEL; MASTERS, 2014). Os espaços de coworking, surgiriam em decorrência do desenvolvimento desse cenário, em um momento em que mais uma vez, as transformações da economia impeliriam por novos arranjos no mundo do trabalho.

Quando olhamos para o contexto de surgimento e para as características das startups e dos coworkings, vemos que, quase como um tipo ideal, o Vale do Silício reflete toda uma nova configuração tanto das formas de se produzir e criar valor como da própria relação entre os trabalhadores e a própria ideia de trabalho. $\mathrm{O}$ Vale do Silício nos permite ver de forma prática como se constituiu um amálgama coerente e complementar entre a $1^{\circ}$ ) demanda por um novo modelo de produção frente a uma crise econômica, $2^{\circ}$ ) as novas tecnologias decorrentes dessa demanda e consequentemente, $3^{\circ}$ ) as novas subjetividades, forjadas por novos valores desencadeados a partir dessa nova configuração por meio da qual os indivíduos passaram a definir seus desejos e anseios sobretudo no que tange a sua relação com o mundo do trabalho.

Esses são, portanto, segundo Martel (2015) os ingredientes fundamentais que configuraram o diferencial do Vale - e que o asseguram como primeiro local procurado por jovens empreendedores, das mais variadas línguas e culturas em busca de fazer com que suas ideias saiam do papel: um local cuja a atmosfera estimula o empreendedorismo e toda a coragem frente os riscos, desafios e incertezas que ele lança. Em suas palavras, mais do que um ponto geográfico em si, o Vale corresponderia a um estado de espírito, estado esse que viria atravessar a essência das startups e dos espaços de coworking por todo mundo.

\section{A bolha da internet}

As startups ganham notoriedade como modelo de empreendimento na década de 1990. É nesse mesmo período que se configura a grande bolha da internet conhecida também como dot-com mania ou dot-com bubble, e o Vale do Silício, devido a quantidade de investimentos voltados à tecnologia que se encontravam concentrados ali, ficou conhecido como o epicentro desses acontecimentos.

Da metade dos anos 1990 a 2001, o setor da internet, juntamente com as indústrias de alta tecnologia a ele relacionadas, cresceram rapidamente, devido principalmente a grande quantidade de capital de risco disponível e criaram uma nova onda de crescimento no Vale do Silício. O mercado de ações, como a NASDAQ onde diversas corporações voltadas para a tecnologia faziam parte da lista, experimentaram uma grande alta no preço de suas ações. Em março de 2000, a NASDAQ alcançou o pico de 5.132.52 (MANN \& NUNES, 2009, p.2, tradução nossa). 
Existem análises sobre períodos de formação das bolhas. Trata-se de um fenômeno de mercado já conhecido e que pode ser entendido como um movimento retórico do mesmo, isso porque as bolhas não seriam meras explosões irracionais, mas situações que ocorrem a partir da interinfluência de ações estratégicas que envolvem compradores, vendedores, banqueiros e agências governamentais. As bolhas, portanto, seriam uma interligação de práticas discursivas e materiais que gerariam um cenário de confiança, ambição e especulação. Elas se formam não em consequência de mera imitação dos modelos racionais e lógicos do mercado, mas se definem quando existem a emulação de empreendimentos inovadores e incertos (GOODNIGHT; GREEN Jr., 2010).

Entender a proliferação das startups em perspectiva com o momento do crescimento e estouro da bolha da internet nos permite visualizar na prática como essa nova cultura empreendedora está intimamente relacionada à uma transformação da cultura de risco do mercado. Por sua vez, olhar para a transformação da racionalidade do mercado sobre o que ele entende por risco é também levar em consideração todos os agentes e suas respectivas dimensões envolvidas nesse processo. A bolha da internet foi capaz de demonstrar como as articulações políticas, econômicas e sociais que se deram no contexto do Vale do Silício foram capazes de reconfigurar em um curto período de tempo os valores que balizam o nível de confiança dentro da esfera econômica.

Uma cultura de risco combinada que sustenta, ajusta ou revoluciona práticas de qualquer setor econômico em particular é influenciada por intervenções estatais. Muitas novas bolhas de tecnologia do século XX têm sido colaborações públicas e privadas. No caso das pontocom, enquanto o mercado espiralou através de controvérsias de legitimação, impulso em cascata e reviravoltas reflexivas, o governo federal promulgou políticas fiscais, regulatórias e monetárias para estimular - ao mesmo tempo em que seus poderes se tornaram atrativos - uma nova revolução tecnológica. (GOODNIGHT; GREEN Jr., 2010, p.120, tradução nossa).

Os EUA promoviam na década de 1990 condições favoráveis a um estado eufórico de mercado, sobretudo no que dizia respeito à tecnologia. $\mathrm{O}$ crédito era abundante, a economia estava indo de vento em popa, o cenário político emanava confiança por meio de medidas governamentais que baixavam os juros e realocavam investimentos que antes eram voltados para a manutenção da Guerra Fria, agora para o fortalecimento das áreas de tecnologia e informação. Todos esses elementos compunham um cenário propício à aposta de investidores locais e estrangeiros. Essa atmosfera era reforçada por uma narrativa midiática que falava em uma "superestrada para informação" e na "media mania" como um dos maiores passos da 


\section{Depois do pós-fordismo: as últimas décadas da razão material do trabalho}

comunicação desde a invenção do transistor. Esses componentes, juntos, faziam das novas tecnologias a ponte para um mundo revolucionário e, consequentemente, um novo mercado de investimentos (GOODNIGHT; GREEN Jr., 2010). Dessa forma, não só os elementos materiais disponíveis, mas todo um suporte discursivo - que envolvia especialmente o campo político e suas diretrizes neoliberais - se fazia presente para que uma nova racionalidade abrisse caminho para um novo perfil de trabalhador.

O fato é que, em um cenário traçado por tantas novidades, era natural que os acontecimentos não fossem antecipadamente previstos pelos analistas econômicos. As regras para a avaliação desse novo momento ainda não existiam, ou então, estavam em processo de formação. Os investidores ignoravam as fórmulas tradicionais de análise dos riscos e, consequentemente, uma mudança na cultura do investimento de mercado também acontece. É sob essas circunstâncias que ocorre a proliferação das startups. Em 1999, pouco antes da bolha estourar, foram abertos 446 novos empreendimentos na área de tecnologia. Foram 18 meses que ficaram conhecidos como a Segunda Corrida do Ouro no Vale do Silício. Tratouse de um momento de grandes investimentos nessa região, onde milhares de pessoas, principalmente jovens que se consideravam com uma ideia potencialmente inovadora, começam a viabilizar estratégias a fim de se juntar e criar alguma startup no local (THIEL; MASTERS, 2014).

Sucessos espetaculares foram compartilhados por um tempo, e esses não passaram despercebidos. Revistas populares e canais de notícias como a CNBC espalharam histórias de investimento para o entretenimento. A cobertura assumiu um brilho positivo, até mesmo eufórico. "Era quase como um trem que não podia ser parado", lembrou um publicitário. A mídia "adorava se apossar de" fundadores de empresas, transformando geeks desajeitados em titãs industriais, ricocheteando o público com histórias heroicas de trapo à riqueza. Amostras de sucessos precoces alimentaram desejos de aumentar ainda mais o sensacionalismo acerca dos iniciantes. Os capitalistas de risco reagiram multiplicando as oportunidades de e-business em mundos virtuais imaginários de novos produtos e serviços. Pet care? Entrega de pizza? Marcas voltadas para saúde? Ninguém conhecia os limites. Era como se o aparato econômico estivesse voltado para a lógica de que as percepções e o pensamento dos investidores serviam para moldar a realidade. De fato, os efeitos dos aumentos iniciais de preço pareceram criar um "ciclo de retroalimentação" que estimulou o crescente interesse dos investidores. À medida que a bolha se expandia, as lógicas que animavam os especuladores e os recémchegados novatos dividiam-se e ampliavam-se. (GOODNIGHT; GREEN Jr., 2010, p.126-127, tradução nossa). 
Para se ter uma ideia, várias startups desse período conseguiam o retorno de $70 \%$ de seus investimentos logo no primeiro dia de lançamento. Tratava-se realmente de um contexto instigante aos investidores e aqueles que viam nesses modelos uma nova forma de mudar o rumo de suas vidas (GOODNIGHT; GREEN Jr., 2010).

As contas online cresceram de 3,7 milhões em 1997 para 10 milhões em 1999. Em retrospectiva, esse tipo de transformação popular é inevitavelmente descrito como uma psicologia da "euforia" que induz uma "mania" de investir a qualquer preço. Mais que isso, a própria tecnologia da internet incluiu novatos em poderosas estruturas de informação. Esses investidores tinham mais dados para trabalhar do que nunca, mas os sistemas de comunicação alimentavam a confiança com as salas de bate-papo on-line, povoadas com mais frequência por entusiastas que compartilhavam da mesma opinião. Além disso, os relatórios de mídia de massa interagiram com as novas tecnologias e induziram uma quantidade sem precedentes de investimento pessoal. Os trabalhadores estavam deixando o emprego para se tornarem heróis da mídia. Em um cibercafé, é possível ler gráficos, reunir notícias, colocar ou retirar dinheiro em tempo real e obter lucro tudo com um latte antes do almoço. (GOODNIGHT; GREEN Jr., 2010, p.127, tradução nossa).

Todos esses sucessos iniciais alimentavam o desejo de investidores e trabalhadores que deixavam seus antigos empregos em busca de criar alguma ideia inovadora que pudesse ganhar a confiança do mercado. Se existem momentos em que a condição pós-fordista de euforia e instabilidade pudesse ser representada, a bolha da internet sem dúvida é um deles. Por isso, esse momento também revelava uma outra condição. Por serem basicamente ideias de negócios inovadoras e em fase inicial, ou seja, ainda em estágio de realização de testes e em busca de investimentos, muitas startups e seus respectivos empreendedores, eram considerados excêntricos e extravagantes, o que, com o tempo, passou a ser uma das características do próprio Vale do Silício (MISKOLCI, 2014). Além disso, muitos desses negócios, principalmente durante esse período da dot-com mania, não chegaram nem a se realizar, o que fez com que seus fundadores fossem chamados de empreendedores de papel.

A Dot-com mania foi intensa, mas curta - 18 meses de insanidade de setembro de 1998 a março de 2000. Era uma corrida de ouro do Vale do Silício: havia dinheiro em todos os lugares, e uma abundância de pessoas exuberantes, muitas vezes esquisitas, para persegui-lo. Todas as semanas, dezenas de novas startups competiram para lançar a mais luxuosa festa de lançamento. [...] Os milionários de papel acumulariam milhares de dólares em jantares e tentariam pagar com as ações 


\section{Depois do pós-fordismo: as últimas décadas da razão material do trabalho}

de sua empresa - às vezes, isso funcionava. Legiões de pessoas abandonaram seus empregos bem pagos para fundar ou juntar-se aos startups. (THIEL; MASTERS, 2014, p.16, tradução nossa).

Assim, apesar da confiança do mercado, a bolha já era algo inevitável diante do tamanho do fluxo de capital e investimento de risco que passou a se concentrar na região do Vale do Silício a partir da década de 1970, mas que se intensificou nos últimos anos da década de 1990. Nesse período, os preços das ações da Internet nos Estados Unidos "aumentaram quase cinco vezes e a taxa de crescimento do patrimônio líquido acelerou de 10,4 por cento ao ano entre 1990 e 1995 para 21,2\% ao ano entre 1995 e 2000" (KRAAY; VENTURA, 2005, p.2-3, tradução nossa). No entanto, foi entre os anos de 1998 e 2000, aproximadamente em um intervalo de 18 meses, que "o setor de Internet ganhou mais de 1000 por cento de retorno em ações públicas. Na verdade, nessa data, o setor da Internet equivalia a $6 \%$ da capitalização de mercado de todas as empresas públicas dos EUA e $20 \%$ de todo o volume de ações negociadas publicamente". (OFEK; RICHARDSON, 2003, p.1113, tradução nossa).

Em síntese, a bolha da internet tem início com a popularização da rede e dos computadores. Esse movimento mudou a forma de consumir e, consequentemente, criou um novo mercado. E-commerces e sites de buscas começam a se proliferar com uma rapidez tremenda e ganham uma grande aceitação de público consumidor em decorrência da novidade que representavam. Todo mundo queria "surfar" na internet. Os investimentos milionários e especulações no mesmo nível se alastram. Muitos investidores, dos mais variados tamanhos começam a injetar dinheiro em novos empreendimentos ao mesmo tempo. Todos queriam ter seu nome ou negócio conectado ao ramo ponto.com. Não demorou muito e empresas começam a ter valores muito elevados junto à bolsa NASDAQ, onde ocorriam as negociações da internet. Algumas delas, como a The Globe, só para tomarmos de exemplo, chegou a subir 606\% em seu primeiro dia de IPO's - como são conhecidas as ofertas públicas de ações. Em março de 2000, o índice NASDAQ que girava em torno de 1000 pontos subiu para 5000, cravando seu pico mais alto na história. O valor combinado das ações na época era de 6 trilhões e 71 bilhões (A HISTÓRIA...2000).

A alta confiança do mercado, adicionado ao alto valor de capital disponível, mais a baixa de juros proporcionada pelo governo americano e uma grande parcela de empreendedores despreparados formavam um contexto econômico especulativo instigante, porém prestes a entrar em colapso. Em 10 de março a bolha estoura e o preço das ações cai $4 \%$ só no primeiro dia. A partir de então, empresas começam a perder seu valor drasticamente. Para se ter uma ideia, a The Globe, exemplo acima citado, depois do estouro da bolha passa a ter suas ações valendo por volta de US $\$ 0,16$ centavos. 
Gráfico 1 - NASDAQ antes, durante e depois da Bolha da Internet

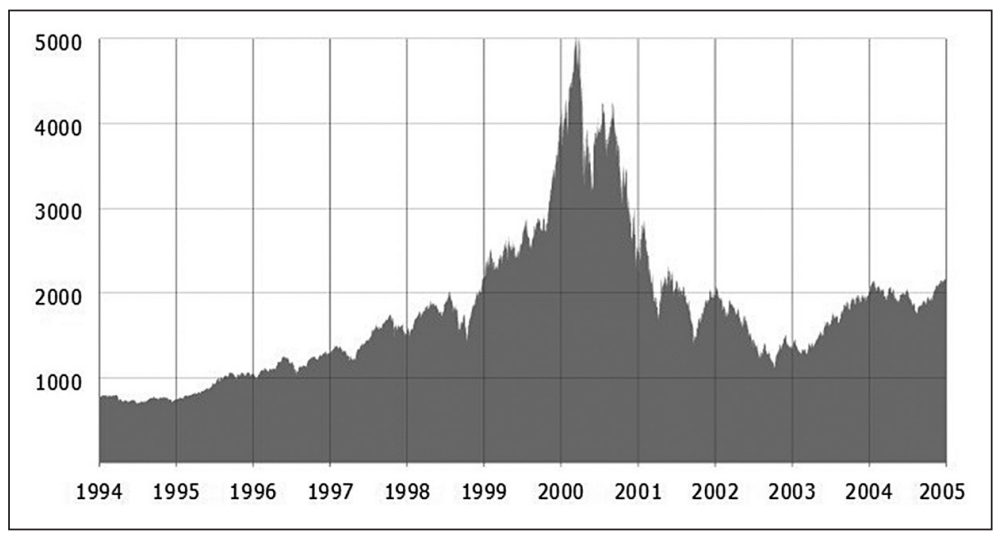

Fonte: https://www.tecmundo.com.br/mercado/124475-historia-estouro-bolhada-internet-ano-2000-video.htm

Entender a formação do Vale do Silício, mas sobretudo especificamente o cenário que se deu por lá dos últimos anos do século XX nos ajuda a visualizar os elementos que passaram a fazer parte da racionalidade de mercado - tanto das empresas quanto dos investidores - e dos trabalhadores envolvidos com inovação de maneira geral. Tratou-se de uma transformação da cultura do investimento e dos riscos de mercado que acabou por influir diretamente na construção de um perfil ideal de trabalhador para determinados contextos de incerteza e instabilidade. Por isso, o advento da bolha e todas as condições contextuais que a tornaram possíveis são exemplos ilustrativos do momento em que passa a ser moldado esse novo perfil, não só porque mobilizaria atributos técnicos e práticos, mas porque transformaria toda a interpretação e desejo dos profissionais em favor de da potencialização de um mercado que pautaria sua legitimidade na exaltação da flexibilidade e do empreendedorismo como atributo necessário para lidar com momentos de instabilidade e incerteza.

\section{Conclusão}

Quando falamos do surgimento das startups e dos espaços de coworking, nosso argumento é de que se trata não só da estratégia de uma mão de obra oriunda da onda de desemprego decorrente dos processos de reengenharia do mercado de trabalho implementados pelas grandes empresas nas últimas décadas do século XX e fortemente sentida nos EUA (SENNETT, 2009) - concomitante aquilo que mais tarde seria visto como um dos reflexos do desfalecimento do estado de bem estar 
social -, como também uma questão geracional, ou seja, um caminho natural entre os trabalhadores mais jovens, que já nascerem em meio a essa nova condição. E muito dessa nova condição, ou seja, dessa nova forma de interpretar o mundo do trabalho e as maneiras de se posicionar em meio a ele, foi construída em confluência das transformações de mercado que alteraram a percepção de risco e responsabilidade sobre o desempenho por parte dos trabalhadores. Essas transformações fazem com que vários elementos sejam naturalizados, em especial o caráter empreendedor, a flexibilidade, a adaptação, a ânsia constante por inovação e manutenção do capital humano, todos como chaves para empregabilidade em um mundo do trabalho pósfordista. Diferente de um trabalhador que viveu todos os arranjos da década de 70 e 80 e teve que se reinventar, o trabalhador mais jovem já traz em sua formação profissional atributos coerentes e desejáveis para um mundo do trabalho cada vez mais flexibilizado, não precisando necessariamente passar por um processo de adaptação a essas transformações. Muitos deles nem chegaram a ter empregos formais, baseados em contratos de trabalho tradicionais como os de antigamente, e já entram no mercado fazendo uso da lógica empreendedora, ou seja, em nosso caso, decididos a rentabilizar suas próprias ideias por meio dos modelos de startups. Outros, por sua vez, deixaram seus empregos para se aproveitar desse momento propício (THIEL; MASTERS, 2014). A tendência de um perfil de trabalhador já preparado para essas condições vem se mantendo durante os últimos anos.

Como vemos, o Vale do Silício concentrou em um só local as maiores criações tecnológicas que deram base ao mundo conectado e informacional tal qual conhecemos hoje, e o terreno necessário para que empreendimentos - sobretudo pautados na ciência, informação e conhecimento - ganhassem o fôlego e motivação para dar conta de duas das maiores demandas da organização socioeconômica pós-fordista: a flexibilidade e a inovação. Apesar da bolha da internet ter sido o grande momento da proliferação das startups, todo aparato tecnológico que se foi possível criar no Vale do Silício, possibilitou que em torno dele se construísse um ecossistema político, econômico e social que, apesar dos altos e baixos do mercado ligado às novas tecnologias e à internet, se mantém como atrativo para jovens com perspectivas de empreender. É a partir de um contexto já estabelecido da década de 1990, que as startups passam a consolidar na prática o discurso do empreendedorismo que irá se espalhar ao redor do mundo. Por isso que, em grande medida, entender os modelos de trabalho que surgiram nesse contexto, como as startups e os espaços de coworking, nos impeliu a entender do que se tratava as condições que os tornaram possíveis. Pensar as origens do Vale do Silício e suas principais transformações é pensar sobre as origens das startups, pois foram elas que amplificaram todo o aparato material e simbólico que permitiu que aquela região fosse conhecida hoje como a meca do empreendedorismo, ou então, a Hollywood da tecnologia (NORMAND, 2014). 
A história do Vale do Silício - e em especial o episódio da bolha da internet, nos permite entender os motivos pelos quais as startups e também os espaços de coworking são produtos de uma nova fase capital. Mais do que isso: se define uma complementaridade entre esses dois fenômenos que colabora e se torna cada vez mais fundamental para a manutenção do espírito empreendedor desses trabalhadores, espírito esse que se tornou essencial para a própria reprodução do capitalismo flexível e que se pauta incisivamente sobre o desejo e afeto dos trabalhadores em relação ao próprio trabalho - e consequentemente à suas condições - como forma de motivá-los nessa engrenagem instável e imprecisa das formas de trabalho pósfordistas, representada pelos modelos e formas de organização de trabalho flexíveis.

\section{AFTER POST-FORDISM: THE LAST DECADES OF THE MATERIAL REASON FOR LABOUR}

ABSTRACT: There are innumerable ways in which the labor market tried to deal with economic changes in the last 50 years. Among these transformations, flexibilization points the new dynamics of production and organization of workers. This article aims to reflect on the transformations resulted from the productive restructuring, observing how, based on this scenario of stagnation in Fordism perceived as a result of the rigidity and bureaucracies present in the organization of production, distribution and in the markets -, demands not only from consumers, but also from workers, could no longer be served. The article focuses on the emergence of a new worker profile, demanded from the new dynamics of market flexibility and a new rationality regarding work which, at the beginning of the 21st century, will be reflected in new models of organization and work management, such as startups and co-workings.

KEYWORDS: Post-Fordism. Productive restructuring. Silicon Valley. Startups. Coworkings.

\section{DESPUÉS DEL POSTFORDISMO: LAS ÚLTIMAS DÉCADAS DE LA RAZÓN MATERIAL DE TRABAJO}

RESUMEN: Hay innumerables formas en que el mercado laboral ha tratado de hacer frente a los cambios económicos de los últimos 50 años. Entre estas transformaciones, la flexibilidad marca la nueva dinámica de la producción y la organización de los trabajadores. Este ensayo pretende reflexionar sobre las 
transformaciones derivadas de la reestructuración productiva y cómo, de ellas, surge un nuevo perfil del trabajador, exigido por la nueva dinámica de la flexibilidad del mercado y por una nueva racionalidad del trabajo que, a principios del siglo $X X I$, se reflejan en medio de nuevos modelos de organización y gestión del trabajo, como las startups y los coworkings. Este es el fragmento de una discusión planteada en la tesis doctoral titulada "No fue amor, fue una trampa: la puesta en marcha, el trabajo en equipo y la movilización del deseo por el mundo del trabajo", en la que se trata de hacer apuntes elementales sobre el fortalecimiento del discurso neoliberal del emprendimiento de uno mismo a partir de sujetos situados en Silicon Valley (EE.UU.).

PALABRAS CLAVE: Postfordismo. Reestructuración productiva. Silicon Valley. Startups. Coworkings.

\section{REFERÊNCIAS}

A HISTÓRIA e o estouro da bolha da internet do ano 2000. Tecmundo. Vídeo. Tempo: 10’30", 12 dez. 2017. Disponível em: https://www.tecmundo.com.br/mercado/124475historia-estouro-bolha-da-internet-ano-2000-video.htm . Acesso em: 03 ago. 2018.

ALVES, G. Trabalho e Subjetividade: o espírito do toyotismo na era do capitalismo manipulatório. São Paulo: Boitempo, 2011. 168 p.

ATHIQUE, A. Digital Media and Society: an Introduction. Cambridge, Polity Press, 2013. $295 \mathrm{p}$.

BOLTANSKI, L.; CHIAPELLO, È. O novo espírito do capitalismo. Tradução Ivone C. Benedetti, revisão técnica Brasílio Sallum Jr. 1. ed. São Paulo: Martins Fontes, 2009. 704 p.

CASTELLS, M. A galáxia da internet: reflexões sobre a internet, os negócios e a sociedade. Tradução Maria Luiza X. de A. Borges, revisão Paulo Vaz. 1. ed. Rio de Janeiro: Jorge Zahar Ed, 2003. 244 p.

DESKMAG. The 2017 Global Coworking Survey. 2017. Disponível em: http://www. deskmag.com/en/background-of-the-2017-global-coworking-survey. Acesso em: 06 ago. 2017.

DULLIUS, A. C. As capacidades de inovação em startups: um estudo no Vale do Silício. 2016. 166 f. Dissertação (Mestrado em Administração) - Pós-Graduação em Administração, Universidade Federal do Rio Grande do Sul. Porto Alegre. Disponível em: https://lume.ufrgs. br/handle/10183/143320. Acesso em: 02 jul. 2016. 
FIRST ROUND. State of Startpups, 2017. Disponível em: https://stateofstartups2017. firstround.com/. Acesso em: 06 set. 2017.

GITAHI, Yuri. O que é uma startup? Exame. 3 fev. 2010. Disponível em http://exame.abril. com.br/pme/noticias/o-que-e-uma-startup/ . Acesso em: 02 out. 2014.

GOODNIGHT, T. G.; GREEN JR, S. E. Rhetoric, Risk, and Markets: The Dot-Com Bubble. Quarterly Journal of Speech. n. 96, p.115-140, jun. 2010. Disponível em: https://www. researchgate.net/publication/248927361_Rhetoric_Risk_and_Markets_The_Dot-Com_ Bubble. Acesso em: 05 set. 2017.

HARDT, M.; NEGRI, A. Império. Tradução Berilo Vargas. 2. ed. Rio de Janeiro: Record, $2001.503 \mathrm{p}$.

HARVEY, D. Condição pós-moderna: uma pesquisa sobre as origens da mudança cultural. Tradução Adail Ubirajara Sobral, Maria Stela Gonçalves. 23. ed. São Paulo: Loyola, 2012. $352 \mathrm{p}$.

KRAAY, A.; VENTURA, J. The dot-com bubble, the bush deficits and the U.S. current account. NBER Working Paper. n. 11543. Agosto, 2005. Disponível em: https://www.nber. org/papers/w11543. Acesso em: 19 abr. 2017.

LAVAL, C.; DARDOT, P. A nova razão do mundo: ensaio sobre a sociedade neoliberal. Tradução Mariana Echaclar. São Paulo: Boitempo, 2016. 416 p.

LAWS, D. Who named Silicon Valley? CHM - Computer, History, Museum. January, 2015. Disponível em: https://computerhistory.org/blog/who-named-silicon-valley/?key=whonamed-silicon-valley . Acesso em: 07 jul. 2020.

MANN, A. and NUNES, T. After the Dot-Com Bubble: Silicon Valley high-tech employment and wages in 2001 and 2008. August 2009. U.S. Bureau of Labor Statistics. Regional Reports. Disponível em: http://www.bls.gov/opub/regional_reports/200908_silicon_valley_ high_tech.htm. Acesso em: 07 jul. 2020.

MARTEL, F. Smart: o que você não sabe sobre a internet. Tradução Clóvis Marques. 1. ed. Rio de Janeiro: Civilização Brasileira, 2015. 462 p.

MISKOLCI, R. San Francisco e a nova economia do desejo. Lua Nova, São Paulo, n. 91, p.269-295, 2014. Disponível em: http://www.scielo.br/scielo.php?pid=S010264452014000100010\&script=sci_abstract\&tlng=pt . Acesso em: 19 abr. 2017.

MORRIS, R; PENIDO, M. Como o Vale do Silício se tornou o Vale do Silício? [S.l.]: Endeavor Global, 2014. Disponível em: https://endeavor.org.br/ambiente/como-o-valesilicio-se-tornou-o-vale-silicio/. Acesso em: 25 set. 2017. 


\section{Depois do pós-fordismo: as últimas décadas da razão material do trabalho}

NORMAND, R. Vale do Silício: entenda como funciona a região mais inovadora do planeta. [S.l: s. n.], 2014. Disponível em: www.valedosilicio.com. Acesso em: 23 set. 2017.

OFEK, E.; RICHARDSON, M. DotCom Mania: The Rise and Fall of Internet Stock Prices. The journal of finance. Vol. 58, n. 3, p.1113-1137, jun/2003.

PELBART, P. P. Vida capital: ensaios de biopolítica. Revisão Ariadne Escobar Branco. São Paulo: Iluminuras, 2003. 256 p.

PELISSON, A; HARTMANS, A. The average age of employees at all the top tech companies, in one chart. Business Insider. 11 set. 2017. Disponível em: https:/www.businessinsider. com/median-tech-employee-age-chart-2017-8. Acesso em: 07 jul. 2020.

RIES, E. A startup enxuta: como os empreendedores atuais utilizam a inovação contínua para criar empresas extremamente bem-sucedidas. Tradução editores. São Paulo: Leya, 2012. $288 \mathrm{p}$.

SAWAYA, Márcia Regina. Dicionário de Informática e Internet. São Paulo: Nobel, 1999. Disponível em: https:/nosda18.files.wordpress.com/2009/04/dicionariode-informatica-einternet.pdf. Acesso em: 07 jul. 2020.

SCHUMPETER, J. A. Teoria do desenvolvimento econômico: uma investigação sobre lucros, capital, crédito, juro e o ciclo econômico. Tradução Maria Silvia Possas. São Paulo: Nova Cultural, 1997. 238 p.

SENNETT, R. A corrosão do caráter: as consequências pessoais do trabalho no novo capitalismo. Tradução Marcos Santarrita. 14. ed. Rio de Janeiro: Record, 2009. 206 p.

STANDING. G. O precariado: a nova classe perigosa. Tradução Cristina Antunes. 1. ed. São Paulo: Autêntica, 2013. 288 p.

THIEL, P.; MASTERS, B. Zero to one: notes on startups or how to build the future. New York: Crown Bussiness, 2014. 160 p.

ZANON, B. Rede, coworking e emancipação intangível: um olhar sobre a flexibilidade, biopolítica e subjetividade a partir da reestruturação produtiva. 2015. 114 f. Dissertação (Mestrado em Ciências Sociais) - Programa de Pós-Graduação em Ciências Sociais, Universidade Federal de Uberlândia, Uberlândia, 2015. Disponível em: https://repositorio. ufu.br/bitstream/123456789/12905/1/RedeCoworkingEmancipacao.pdf. Acesso em: 07 jul. 2020 .

Recebido em 28/03/2020.

Aprovado em 31/05/2020. 
